\title{
Comparison between NFC/RFID and Bar Code Systems for Halal Tags Identification: Paired Sample T-Test Evaluation
}

\author{
Mohsen Khosravi, Najma Imtiaz Ali, Mostafa Karbasi*, Imtiaz Ali Brohi, Irfan Ahmed Shaikh **, Asadullah Shah \\ Department of Information Systems, \\ Kulliyah of Information Communication and Technology (KICT), International Islamic University Malaysia, Gombak, \\ Kuala Lumpur, Malaysia \\ *University of Ghiaseddin Jamshed Kashani, Iran \\ **University of Sindh, Jamshoro
}

\begin{abstract}
Malaysia is a modern Muslim country where the research on Halal product identification is at the peak. In this study, the authors have developed the mobile application which is based on Radio frequency identification near field communication RFID/NFC. The author first developed the database based on the data from Jabatan Kemajuan Islam Malaysia JAKIM, which is Malaysian Halal logo identification authority then the mobile application which uses the Near Field Communication to detect the Halal food using the Radio Frequency Identification. In this paper authors have performed the experimental analysis by comparing the Barcode system that is comprised of parallel line detected by the simple webcam for the Halal logo identification and the new developed RFID NFC mobile application. Paired sample T-Test was performed by using the SPSS 23.0 version. The results revealed that there is significantly difference between the usability, efficiency, affordability, security and satisfaction. The users are more satisfied with the newly developed mobile application as compared to old halal logo system in Malaysia.
\end{abstract}

Keywords-Halal products; RFID/NFC; JAKIM; paired sample T-test; Malaysia

\section{INTRODUCTION}

Malaysia is modern Muslim country heading towards being a global Halal hub; it has been well-known as a successful halal-hub in the world since 1997. Halal is often used in reference to food and drinks, i.e. food that is allowable for Muslims to eat or drink under Islamic Shariah (law). Halal is an Islamic religious manual for how Muslims ought to experience their lives from the way their nourishment is set up to how their own and social connections are directed.

In Halal industry, keeping up halal item trustworthiness is a fundamental variable so it is necessary to present a complete and fitting Tracking and Tracing Technology to keep up halal item uprightness and build up an innovative structure that can bolster the whole Halal Product Supply Chain [1]. Information technology (IT) is supposed to be the best formula to be used to make the world a more helpful and viable place for individuals from a wide range of culture and religion. Nowadays, smart spaces and smartphones are going to lead the world of business.
Barcode system is made with the help of Matlab and they are very to detect through the webcam [2] "Near Field Communication (NFC) is short-range, low bandwidth, high frequency, and wireless communication technology built on radio frequency identification (RFID) technology" [3]. RFID refers to Radio Frequency Identification and is a term that portrays an arrangement of ID [4]. RFID depends on putting away and remotely recovering data or information as it comprises of RFID tag, RFID peruse and back-end Database [5].

The mobile RFID empowers business to give new administrations to portable clients by securing administrations and exchanges from the end-client to an organization's current online business and IT frameworks [6]. RFID innovation has been acknowledged as an execution differentiator for an assortment of business applications, yet its capacity is yet to be completely used. In future brilliant spaces, the client ought to have the capacity to utilize his own particular versatile reader gadgets to recognize the things, look for the following thing of intrigue, restrict and explore. Fig. 1 demonstrates how RFID technology works.

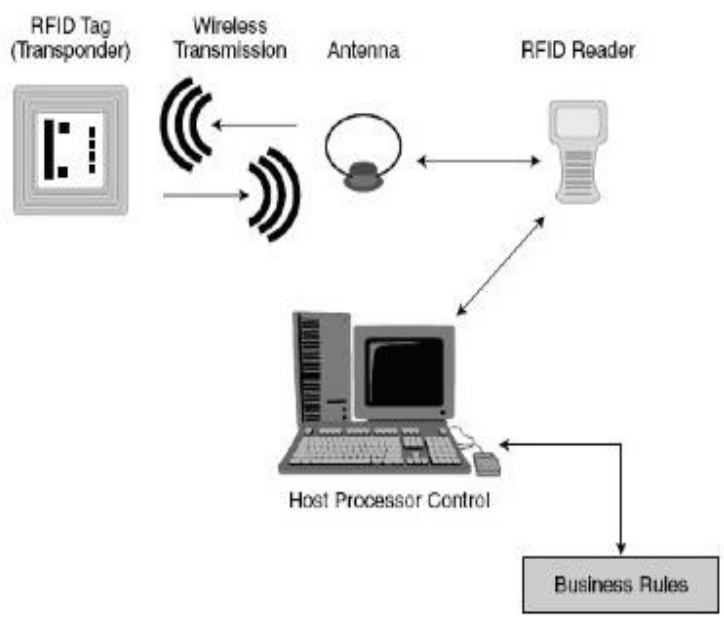

Fig. 1. RFID technology process. 


\section{BACKGROUND}

At the 2007 world halal forum, Malaysia's former Prime Minister, Tun Abdullah Haji Ahmad Badawi stated the government's aim of establishing Malaysia as a global halal hub. Subsequently, a large number of studies were conducted in various disciplines to help pursue the goal of "Malaysia as a global halal hub" [7]. One of the controversial issues in the halal food industry is detecting fake halal products from genuine ones. Malaysian Muslim specialist on the halal item, Jabatan Kemajuan Islam Malaysia (JAKIM) has created and actualized the halal logo as the halal approval due to the demand of market broker organizations. To check the originality of halal products, customers could either browse JAKIM's website or call JAKIM's office via phone.

On the one hand, these methods are time-consuming but on the other hand, cases misrepresentation and abuse of the halal logo have progressively been accounted by purchasers [8]. To handle this issue now some researchers stated to do research on this and have implemented RFID technology while others have suggested using mobile or Smartphone gadget for validating halal products. In the Malaysian Halal industry, RFID innovation is viewed as undeveloped since standardized tags are regularly utilized as programmed identifiers regardless of the presence of web-based interfaces and cell phone applications [9]. However, Muslim consumers still face problems in validating halal products.

My MobiHalal 2.0 is a mobile-based support application for Muslims to identify the Halal status [10] so that users can send and receive MMS as answers to their queries instead of entering 13-character barcodes in the SMS. This study thus discusses the barcode conception and its functions in customer product industry.

Another study has implemented 2-D barcode halal logo detector to identify halal products and UV hologram to spot fake halal logo [11]. The scanned image is decoded and used to match a database. Prototype hardware as halal detector device has also been designed so that the customer can hold the product in front of it, then the status of the product will appear on the device screen.

Another study proposes a system that would help the consumer to validate halal products through Smartphone barcode captured straightaway on time with the applied halal product alert database system [12]. The system is called MyHalal designed to focus on a new database structure which details the company's information, Halal certificate expiry alert and new applications technique using Smartphone without accessing the network. The only operating system that customers need to have is a smartphone with a minimum Android 2.1.

Other researchers have implemented RFID technology to identify and validate halal status [13]. One study states that barcodes, reader and ingredient information by far are not adequate to validate the information claimed by the manufacturer or food producer; instead, a real-time tool is needed to feed users with genuine and validated information to assist user-buying process that is RFID technology. The perception of Malaysian customers was measured and the result indicates users agreed that a real-time system is required for the information dissemination [14].

It is imperative for specialists and makers to give redress data since buyers depend basically on item bundling, including the Halal logo, fixings and producers so as to approve Halal status [15].

\section{EVALUATION}

The important phase of any research is the evaluation process to determine the suitability or accuracy. The NFC enabled RFID mobile application was developed for the Halal logo recognition [16], [17]. The comparison between the Barcode system and the new RFID system was performed. To evaluate this research many qualifications attributed to this application were considered such as usability, efficiency, security, affordability and customer satisfaction. Usability referred to how easy the system interface is for the user and how easily a user can use the system [18]. The identification process might be quick for both using RFID and barcodes technology, but barcodes require special equipment and also more concentration on scanning process. The simplicity of use and inexpensive equipment in RFID identification technology increases the usability of this technology.

Efficiency can be defined as the lowest time by the system to perform the same job as compared to the old system [19]. Additionally, except for other technologies such as barcode reader which reads the codes from a printed reader, RFID does not need to read any pre-printed codes or signs. In order to identify products using barcode system, the reader must be clearly printed and without any damage to the reader. According to experience and studies, barcodes are easy to damage and sensitive to the environment. Moreover, the reader must be clean to obtain more effectiveness scan rates.

Furthermore, images for scanning the barcode, must be properly captured and need more concentration and focus on the capturing process which makes it less efficient. The RFID technology uses a wide range of radio frequency. Therefore, tags are easy to read by any customer and smartphone in any position. The third factor was very important for any system that is security [20], which referred to the process and methodologies to keep the personal data safe and secure [21]. The biggest issues in Halal product identification by consumers in Malaysia are misrepresentations of logos and product certificates. It is necessary to employ the technology which reduces fraudulent activities and increases the confidence of customers on shopping. The existing barcodes and logos are easy to reproduce and cheat the consumers. Therefore, Halal product identification methods, for example, online interface and SMS applications have been introduced to settle this issue. Using web portal has its own difficulties like consumers have to connect to the Internet and know how to search through the web portal. RFID technology offers a better security in product identification by using preregistered unique identification code for each product type. The tags are safe and protected against overwriting and altering the information which increases high security in the identification process.

The fourth factor which was evaluated was affordability it can be defined as "to bear the cost of without serious 
inconvenience" [22]. Despite barcode reader which is fixed to each product, the RFID tags are reusable for any other products or the same product for a long time. Moreover, new NFC tags are inexpensive and easily available which makes them more affordable to use; also the application is free of cost for consumers. The fifth factor which was considered as very imperative is customer satisfaction. Customer satisfaction is at the core of human experience, reflecting our liking of an organization's business activities. High levels of customer satisfaction (with pleasurable experiences are strong predictors of customer retention, customer loyalty, and product repurchase. Customer satisfaction is an important factor to remain in business in this modern world of competition [23]. Customer satisfaction is also a major goal of process improvement plans. Quality characteristics which are described in the previous sections are essential elements for customer satisfaction for this application.

In this section the evaluation is compared with traditional product identification (barcode) with developed RFID. Moreover, the other evaluation characteristics to evaluate the respondents' concern in the questionnaires. Section 1 was comprised of personal behavior including the questions regarding sex, age, householder status, marital status, educational level, job status, income per month, shopping times and system awareness. Section 2 was comprised of 30 questions related to the usability, efficiency, security, affordability and customer satisfaction. It is challenging to compare traditional and developed identification technologies particularly barcodes to newly developed ones like RFID. One had wide testing in uncommercial condition and alternate had restricted business reputation

TABLE I. DEMOgRAPHIC DETAILS OF THE RESPONDENT

\begin{tabular}{|c|c|c|c|c|}
\hline Variable & Category & Frequency & Percentage (\%) & Cumulative \\
\hline \multirow{2}{*}{ Sex } & Male & 111 & 44.4 & 44.4 \\
\hline & Female & 139 & 55.6 & 100.0 \\
\hline \multirow{5}{*}{ Age } & Less than 20 & 25 & 10.0 & 10.0 \\
\hline & 21 to 30 & 48 & 19.2 & 29.2 \\
\hline & 31 to 40 & 109 & 43.6 & 72.8 \\
\hline & 41 to 50 & 40 & 16.0 & 88.8 \\
\hline & Above 50 & 28 & 11.2 & 100.0 \\
\hline \multirow{2}{*}{ Are you a householder } & yes & 177 & 70.8 & 70.8 \\
\hline & No & 73 & 29.2 & 100.0 \\
\hline \multirow{3}{*}{ Marital status } & Single & 65 & 26.0 & 26.0 \\
\hline & Married without children & 57 & 22.8 & 48.8 \\
\hline & Married with children & 128 & 51.2 & 100.0 \\
\hline \multirow{4}{*}{ Education } & Less than High school & 93 & 37.2 & 37.2 \\
\hline & Bachelor & 132 & 52.8 & 90.0 \\
\hline & Master & 20 & 8.0 & 98.0 \\
\hline & Doctoral & 5 & 2.0 & 100.0 \\
\hline \multirow{3}{*}{ Job Status } & Manager & 20 & 8.0 & 8.0 \\
\hline & staff & 30 & 12.0 & 20.0 \\
\hline & customer & 200 & 80.0 & 100.0 \\
\hline \multirow{5}{*}{ Monthly Income (in Ringgit) } & Under $2000 \mathrm{RM}$ & 74 & 29.6 & 29.6 \\
\hline & 2000 t0 $3000 \mathrm{RM}$ & 43 & 17.2 & 46.8 \\
\hline & 3000 t0 $4000 \mathrm{RM}$ & 38 & 15.2 & 62.0 \\
\hline & 4000 t0 5000 & 37 & 14.8 & 76.8 \\
\hline & Above $5000 \mathrm{RM}$ & 58 & 23.2 & 100.0 \\
\hline \multirow{4}{*}{ How often you go for shopping } & Once in a week & 84 & 33.6 & 33.6 \\
\hline & Once in 2 weeks & 67 & 26.8 & 60.4 \\
\hline & Once in 3 weeks & 64 & 25.6 & 86.0 \\
\hline & Once in month & 35 & 14.0 & 100.0 \\
\hline \multirow{2}{*}{ Did you aware of this System } & No & 250 & 100 & 100.0 \\
\hline & yes & 0 & .0 & 00 \\
\hline
\end{tabular}




\section{INSTRUMENT RELIABILITY}

The reliability of items used in the questionnaire was conducted through the consistency test that is an evaluation of Cronbach's Alpha. If the value of Cronbach alpha is 0.7 or above then there is a strong relationship between the items used in the questionnaire [24].

1) Reliability Test for New System (RFID)

The overall Cronbach's alpha reliability for the items in the questionnaire was revealed .936 (Table II). There were total thirty items in the questionnaire. The summary item statistics as in Table III for this construct showed the mean value of the items means was 4.945 as shown in Table III.

TABLE II. RELIABILITY STATISTICS (RFID SYSTEM)

\begin{tabular}{|l|l|l|}
\hline Cronbach's Alpha & $\begin{array}{l}\text { Cronbach's Alpha Based on } \\
\text { Standardized Items }\end{array}$ & No. of Items \\
\hline .936 & .935 & 30 \\
\hline
\end{tabular}

TABLE III. SUMMARY ITEM STATISTICS (RFID SYSTEM)

\begin{tabular}{|c|c|c|c|c|c|c|c|}
\hline & Mean & Min. & Max. & Range & $\begin{array}{l}\text { Max./ } \\
\text { Min. }\end{array}$ & $\begin{array}{l}\text { Varian } \\
\text { ce }\end{array}$ & $\begin{array}{l}\text { No. of } \\
\text { Items }\end{array}$ \\
\hline Item Means & 4.945 & 4.610 & 5.154 & .543 & 1.118 & .021 & 30 \\
\hline $\begin{array}{l}\text { Item } \\
\text { Variances }\end{array}$ & 2.737 & 1.991 & 3.484 & 1.493 & 1.750 & 109 & 30 \\
\hline $\begin{array}{l}\text { Inter-Item } \\
\text { Covariances }\end{array}$ & .896 & -.157 & 2.476 & 2.633 & $\begin{array}{l} \\
15.727\end{array}$ & .290 & 30 \\
\hline
\end{tabular}

Table IV shows individual Cronbach's alpha value for the constructs used for the questionnaire of new RFID/NFC device. There were 6 items in each construct and all having reliability $>0.7$ which is considered as the acceptable [25], [26].

TABLE IV. OVERALL RELIABILITY FOR THE RFID SYSTEM

\begin{tabular}{|l|l|l|l|}
\hline Construct & No. of Items & Cronbach's Alpha & Reliability Result \\
\hline Usability & 6 & 0.915 & Excellent \\
\hline Efficiency & 6 & 0.946 & Excellent \\
\hline Affordability & 6 & 0.931 & Excellent \\
\hline Security & 6 & 0.884 & Good \\
\hline Satisfaction & 6 & 0.931 & Excellent \\
\hline
\end{tabular}

2) Reliability Test for Old System (Bar Code)

The overall reliability statistics of the constructs (Table V) revealed .820 Cronbach's alpha reliability for all construct, which comprised thirty items. The summary item statistics for all construct showed the mean value of the items means was 2.895 as shown in Table VI.

TABLE V. RELIABILITY STATISTICS (BARCODE SySTEM)

\begin{tabular}{|l|l|l|}
\hline $\begin{array}{l}\text { Cronbach's } \\
\text { Alpha }\end{array}$ & $\begin{array}{l}\text { Cronbach's Alpha Based on } \\
\text { Standardized Items }\end{array}$ & No. of Items \\
\hline .820 & .820 & 30 \\
\hline
\end{tabular}

TABLE VI. SUMMARY ITEM STATISTICS (BARCODE SYSTEM)

\begin{tabular}{|l|l|l|l|l|l|l|l|}
\hline & Mean & Min. & Max. & Range & Max. / Min. & $\begin{array}{l}\text { Varianc No. of } \\
\text { e }\end{array}$ & Items \\
\hline Item Means & 2.895 & 2.536 & 3.524 & .988 & 1.390 & .057 & 30 \\
\hline Item Variances & 2.767 & 1.776 & 3.576 & 1.800 & 2.014 & .255 & 30 \\
\hline $\begin{array}{l}\text { Inter-Item } \\
\text { Covariances }\end{array}$ & .364 & -.287 & 2.744 & 3.030 & -9.573 & .499 & 30 \\
\hline
\end{tabular}

Table VII shows the overall reliability of the questionnaire for old Barcode system. There were 6 items in each construct and all having reliability $>0.7$ which is considered as acceptable.

TABLE VII. OVERALL RELIABILITY OF OLD SYSTEM (BAR CODE)

\begin{tabular}{|l|l|l|l|}
\hline Construct & $\begin{array}{l}\text { No. of } \\
\text { Items }\end{array}$ & $\begin{array}{l}\text { Cronbach's } \\
\text { Alpha }\end{array}$ & $\begin{array}{l}\text { Reliability } \\
\text { Result }\end{array}$ \\
\hline Usability & 6 & 0.814 & Good \\
\hline Efficiency & 6 & 0.950 & Excellent \\
\hline Affordability & 6 & 0.930 & Excellent \\
\hline Security & 6 & 0.843 & Good \\
\hline Satisfaction & 6 & 0.733 & Acceptable \\
\hline
\end{tabular}

A. Descriptive Analysis New System (RFID System)

In order to perform the parametric test, such paired sample T-test which was performed to evaluate the mean difference data should be normalized [27], [1], therefore authors have performed the descriptive analysis before performing the $\mathrm{T}$ test. This section presents descriptive statistics of survey for a new system that is RFID based system, descriptive analysis is mandatory to conduct in order to perform the paired sample Ttest to see whether our data is normalized or not. The descriptive analysis for the new system as follows.

To measure the usability, efficiency, security affordability and customer satisfaction of RFID (NFC) system, the survey respondents were first asked to indicate their level of agreement with the usability of the new system on a sevenpoint Likert scale ranging from 1 (Strongly disagree) to 7 (Strongly agree). Six items survey instrument were used to measure this construct. The results of the respondents' ratings for each item of this construct are reported as follows. The data is normalized if the value of Skewness and Kurtosis fall between (less than \pm 1 ) and the mean values should be more than Neutral value [27] i.e. 4 in this research. The mean scores for usability as shown in Table VIII was ranged between 4.99 (1.688) and 5.12(1.825), the mean values are above the neutral value (i-e 4), that shows that the new system is easy to be used by the respondent, while data normality values i-e Skewness and Kurtosis found between the acceptable range (less than \pm 1) The mean scores for efficiency as shown in Table IX was ranged between 4.95 (1.555) and 5.12(1.408), which indicates that users are satisfied with the efficiency of new system, however data normality values i.e. Skewness and Kurtosis found between the acceptable range (less than +1 ). Furthermore, the mean scores values for affordability shown in Table X was ranged between 4.68 (1.609) and 4.91(1.562), while data normality values i.e. Skewness and Kurtosis found between the acceptable range (less than +1 ), which indicates 
that the new system can be afforded by the customers. The mean scores for security was ranged between 4.70 (1.669) and 5.11(1.594) as shown in Table XI, which indicates that users are satisfied with the security of the new system, furthermore, the data normality values i.e. Skewness and Kurtosis found between the acceptable range (less than +1 ). The descriptive analysis for the customer satisfaction was evaluated as mean scores ranged between 4.61 (1.724) and 5.12(1.555) as shown in Table XII, While data normality values i.e. Skewness and Kurtosis found between the acceptable range (less than \pm 1 ), which shows the satisfaction of the customer with the new system.

TABLE VIII. DESCRIPTIVE STATISTICS OF MEASURED ITEMS OF USABILITY FOR RFID NFC SySTEM NFC SySTEM

\begin{tabular}{|l|l|l|l|l|l|}
\hline & $\begin{array}{l}\text { Mean } \\
\text { Statistics }\end{array}$ & Std. Deviation Statistics & $\begin{array}{l}\text { Variance } \\
\text { Statistics }\end{array}$ & $\begin{array}{l}\text { Skewness } \\
\text { Statistics }\end{array}$ & Kurtosis Statistics \\
\hline U1 & 5.01 & 1.864 & 3.474 & -.858 & -.346 \\
\hline U2 & 5.08 & 1.786 & 3.190 & -.842 & -.357 \\
\hline U3 & 5.12 & 1.825 & 3.332 & -.820 & -.406 \\
\hline U4 & 4.95 & 1.760 & 3.098 & -.813 & -.213 \\
\hline U5 & 5.08 & 1.688 & 2.850 & -.772 & -.328 \\
\hline U6 & 4.99 & 1.668 & 2.783 & -.787 & -.193 \\
\hline
\end{tabular}

TABLE IX. DESCRIPTIVE STATISTICS OF MEASURED ITEMS OF EFFICIENCY FOR RFID NFC SYSTEM NFC SYSTEM

\begin{tabular}{|l|l|l|l|l|l|}
\hline & $\begin{array}{l}\text { Mean } \\
\text { Statistics }\end{array}$ & Std. Deviation Statistics & $\begin{array}{l}\text { Variance } \\
\text { Statistics }\end{array}$ & $\begin{array}{l}\text { Skewness } \\
\text { Statistics }\end{array}$ & Kurtosis Statistics \\
\hline EF1 & 4.98 & 1.603 & 2.570 & -.705 & -.335 \\
\hline EF2 & 5.00 & 1.627 & 2.647 & -.750 & -.275 \\
\hline EF3 & 4.95 & 1.555 & 2.419 & -.675 & -.248 \\
\hline EF4 & 4.96 & 1.561 & 2.436 & -.693 & -.256 \\
\hline EF5 & 5.02 & 1.557 & 2.425 & -.676 & -.312 \\
\hline EF6 & 1.408 & 1.983 & -.642 & -.420 \\
\hline
\end{tabular}

TABLE X. DESCRIPTIVE STATISTICS OF MEASURED ITEMS OF AFFORDABILITY FOR RFID NFC SYSTEM

\begin{tabular}{|l|l|l|l|l|l|}
\hline & $\begin{array}{l}\text { Mean } \\
\text { Statistics }\end{array}$ & Std. Deviation Statistics & $\begin{array}{l}\text { Variance } \\
\text { Statistics }\end{array}$ & $\begin{array}{l}\text { Skewness } \\
\text { Statistics }\end{array}$ & Kurtosis Statistics \\
\hline AF1 & 4.72 & 1.713 & 2.935 & -.675 & -.514 \\
\hline AF2 & 4.91 & 1.562 & 2.441 & -.745 & -.096 \\
\hline AF3 & 4.72 & 1.687 & 2.846 & -.517 & -.676 \\
\hline AF4 & 4.80 & 1.751 & 3.067 & -.614 & -.708 \\
\hline AF5 & 4.81 & 1.683 & 2.834 & -.526 & -.706 \\
\hline AF6 & 4.68 & 1.609 & 2.590 & -.408 & -.727 \\
\hline
\end{tabular}

TABLE XI. DESCRIPTIVE STATISTICS OF MEASURED ITEMS OF AFFORDABILITY FOR RFID NFC SYSTEM

\begin{tabular}{|l|l|l|l|l|l|}
\hline & $\begin{array}{l}\text { Mean } \\
\text { Statistics }\end{array}$ & Mean Statistics & $\begin{array}{l}\text { Std. } \\
\text { Deviation } \\
\text { Statistics }\end{array}$ & $\begin{array}{l}\text { Variance } \\
\text { Statistics }\end{array}$ & Skewness Statistics \\
\hline SE1 & 5.11 & 1.594 & 2.541 & -.733 & -.245 \\
\hline SE2 & 5.01 & 1.532 & 2.347 & -.721 & -.099 \\
\hline SE3 & 4.70 & 1.669 & 2.784 & -.522 & -.657 \\
\hline SE4 & 5.03 & 1.574 & 2.479 & -.684 & -.285 \\
\hline SE5 & 5.03 & 1.585 & 2.511 & -.800 & -.081 \\
\hline SE6 & 4.95 & 1.695 & 2.872 & -.774 & -.313 \\
\hline
\end{tabular}

TABLE XII. DESCRIPTIVE STATISTICS OF MEASUREd ITEMS OF SATISFACTION FOR RFID NFC SYSTEM

\begin{tabular}{|l|l|l|l|l|l|}
\hline & $\begin{array}{l}\text { Mean } \\
\text { Statistics }\end{array}$ & Std. Deviation Statistics & $\begin{array}{l}\text { Variance } \\
\text { Statistics }\end{array}$ & $\begin{array}{l}\text { Skewness } \\
\text { Statistics }\end{array}$ & Kurtosis Statistics \\
\hline SAT1 & 5.12 & 1.555 & 2.418 & -.708 & -.318 \\
\hline SAT2 & 4.88 & 1.598 & 2.555 & -.596 & -.443 \\
\hline SAT3 & 5.02 & 1.629 & 2.653 & -.558 & -.646 \\
\hline SAT4 & 4.61 & 1.724 & 2.973 & -.357 & -.913 \\
\hline SAT5 & 4.96 & 1.782 & 3.176 & -.723 & -.562 \\
\hline SAT6 & 5.03 & 1.682 & 2.830 & -.763 & -.320 \\
\hline
\end{tabular}

\section{B. Descriptive Analysis for Old System (Bar Code)}

This section presents descriptive statistics of survey for the old system that is Bar Code based system.

To measure the customer satisfaction towards the old system, the survey respondents were also asked to indicate their level of agreement with the usability, efficiency, affordability, security and customer satisfaction on a sevenpoint Likert scale ranging from 1 (Strongly disagree) to 7 (Strongly agree). The same six items survey instrument was used to measure the construct that we used for the new system. The mean scores for the usability ranged between 2.85 (1.707) and 3.52(1.878) as shown in Table XIII, which indicates the means values lower than the neutral value (i.e. 4) it shows that 
the old system is not that much user friendly and not easy to use while data normality values i.e. Skewness and Kurtosis found between the acceptable range (less than +1$)$.

The mean scores for the efficiency was ranged between 2.54 (1.333) and 2.61(1.554) as shown in Table XIV, which indicates the means values lower than the neutral value (i.e. 4) therefore the old system is not that much efficient to use. While data normality values i-e Skewness and Kurtosis found between the acceptable range (less than +1$)$. The Mean values for affordability was lower than the neutral value (i-e 4), that indicates that the old system is not affordable by the respondent. The mean scores ranged between 2.54 (1.333) and 2.61(1.554) as shown in Table XV, which indicates the means values lower than the neutral value (i.e. 4) while data normality values i.e. Skewness and Kurtosis found between the acceptable range (less than +1$)$. Additionally, the mean scores ranged between 2.87 (1.693) and 3.02 (1.726) for the security construct, which indicates the means values lower than the neutral value (i.e. 4) it shows that the old system is not that much secure to use. While data normality values i.e. Skewness and Kurtosis found between the acceptable range (less than + 1) as shown in Table XVI.

The mean score for the customer satisfaction was ranged between 2.71 (1.483) and 3.41(1.891) as shown in Table XVII, which indicates the means values lower than the neutral value (i.e. 4) it shows that the old system is not that much secure to use while data normality values i.e. Skewness and Kurtosis found between the acceptable range that is (less than \pm 1 ).

TABLE XIII. DescriPTIVE STATISTICS OF MEASUREd ITEMS OF USABILITY FOR OLd SySTEM

\begin{tabular}{|l|l|l|l|l|l|}
\hline & $\begin{array}{l}\text { Mean } \\
\text { Statistics }\end{array}$ & Std. Deviation Statistics & $\begin{array}{l}\text { Variance } \\
\text { Statistics }\end{array}$ & $\begin{array}{l}\text { Skewness } \\
\text { Statistics }\end{array}$ & Kurtosis Statistics \\
\hline U1 & 2.85 & 1.707 & 2.914 & .990 & .010 \\
\hline U2 & 2.89 & 1.831 & 3.353 & 1.017 & -.063 \\
\hline U3 & 2.81 & 1.519 & 2.308 & 1.001 & .452 \\
\hline U4 & 3.07 & 1.657 & 2.746 & .862 & -.120 \\
\hline U5 & 2.95 & 1.806 & 3.262 & 1.006 & .002 \\
\hline U6 & 3.52 & 1.878 & 3.528 & .417 & -.991 \\
\hline
\end{tabular}

TABLE XIV. DESCRIPTIVE STATISTICS OF MEASURED ITEMS OF USABILITY FOR OLD SYSTEM

\begin{tabular}{|l|l|l|l|l|l|}
\hline & $\begin{array}{l}\text { Mean } \\
\text { Statistics }\end{array}$ & Std. Deviation Statistics & $\begin{array}{l}\text { Variance } \\
\text { Statistics }\end{array}$ & $\begin{array}{l}\text { Skewness } \\
\text { Statistics }\end{array}$ & Kurtosis Statistics \\
\hline EF1 & 2.61 & 1.554 & 2.415 & 1.035 & .270 \\
\hline EF2 & 2.57 & 1.469 & 2.158 & .961 & .188 \\
\hline EF3 & 2.54 & 1.333 & 1.776 & 1.062 & .576 \\
\hline EF4 & 2.56 & 1.455 & 2.118 & .995 & .320 \\
\hline EF5 & 2.57 & 1.469 & 2.158 & .961 & .188 \\
\hline EF6 & 2.54 & 1.333 & 1.776 & 1.062 & .576 \\
\hline
\end{tabular}

TABLE XV. DescriPtive Statistics OF MEASUREd ItEMS OF USABILITY FOR Old SySTEM

\begin{tabular}{|l|l|l|l|l|l|}
\hline & $\begin{array}{l}\text { Mean } \\
\text { Statistics }\end{array}$ & Std. Deviation Statistics & $\begin{array}{l}\text { Variance } \\
\text { Statistics }\end{array}$ & $\begin{array}{l}\text { Skewness } \\
\text { Statistics }\end{array}$ & Kurtosis Statistics \\
\hline AF1 & 3.03 & 1.733 & 3.003 & .856 & -.123 \\
\hline AF2 & 2.84 & 1.796 & 3.225 & .941 & -.104 \\
\hline AF3 & 2.93 & 1.588 & 2.521 & .944 & .001 \\
\hline AF4 & 2.90 & 1.603 & 2.569 & .801 & -.137 \\
\hline AF5 & 2.98 & 1.728 & 2.987 & .912 & .001 \\
\hline AF6 & 2.97 & 1.781 & 3.172 & .823 & -.319 \\
\hline
\end{tabular}

TABLE XVI. DESCRIPTIVE Statistics OF MEASURED ITEMS OF SECURITY FOR Old SySTEM

\begin{tabular}{|l|l|l|l|l|l|}
\hline & $\begin{array}{l}\text { Mean } \\
\text { Statistics }\end{array}$ & $\begin{array}{l}\text { Std,. Deviation } \\
\text { Statistics }\end{array}$ & $\begin{array}{l}\text { Variance } \\
\text { Statistics }\end{array}$ & $\begin{array}{l}\text { Skewness } \\
\text { Statistics }\end{array}$ & Kurtosis Statistics \\
\hline SE1 & 2.92 & 1.633 & 2.668 & .938 & -.004 \\
\hline SE2 & 2.87 & 1.693 & 2.867 & .883 & -.039 \\
\hline SE3 & 3.08 & 1.768 & 3.126 & .801 & -.484 \\
\hline SE4 & 2.98 & 1.826 & 3.333 & .914 & -.240 \\
\hline SE5 & 3.02 & 1.726 & 2.980 & .896 & -.186 \\
\hline SE6 & 3.20 & 1.741 & 3.031 & .705 & -.534 \\
\hline
\end{tabular}

TABLE XVII. DESCRIPTIVE STATISTICS OF MEASURED ITEMS OF USABILITY FOR Old SySTEM

\begin{tabular}{|l|l|l|l|l|l|}
\hline & $\begin{array}{l}\text { Mean } \\
\text { Statistics }\end{array}$ & Std. Deviation Statistics & $\begin{array}{l}\text { Variance } \\
\text { Statistics }\end{array}$ & $\begin{array}{l}\text { Skewness } \\
\text { Statistics }\end{array}$ & Kurtosis Statistics \\
\hline SAT1 & 3.01 & 1.850 & 3.422 & .902 & -.274 \\
\hline SAT2 & 3.41 & 1.891 & 3.576 & .501 & -.928 \\
\hline SAT3 & 3.00 & 1.655 & 2.739 & .820 & .108 \\
\hline SAT4 & 2.75 & 1.658 & 2.749 & .997 & .307 \\
\hline SAT5 & 2.71 & 1.483 & 2.198 & 1.00 & .539 \\
\hline SAT6 & 2.78 & 1.528 & 2.335 & .866 & .303 \\
\hline
\end{tabular}




\section{Paired Sample T-Test}

Paired Sample T-Test can be performed when there is only one group of people and we need to collect data from them on two different occasions, and if there is $\operatorname{sig}(2$ tailed) value less than 0.5 than there is significant difference between the two scores [27]. "A paired-samples T-test compares the mean of two matched groups of people or cases or compares the mean of a single group, examined at two different points in time. If the same group is tested again, on the same measure, the t-test is called a repeated measures t-test" [28]. In this section, we will perform the paired sample T-test between the average means of constructs obtain from the survey of new system data and the old system data. For this purpose, we compute the average means for all the constructs separately for the old system and new system and then we performed the Pair sample T-test between means of new system and Means of the old system as follows.

Paired sample T-test was performed between the usability construct of RFID (NFC) system and the old system. Table XVIII shows that total mean for RFID (NFC) system is 5.0373 whereas total mean for usability of the old system is 3.0147. Table XIX shows the result of paired sample T-test. The mean difference is computed as 2.0226 with standard deviation of 1.953 , whereas the t statistics is 16.360 , degree of freedom df is 249 with p-value that is $\operatorname{sig}(2$-tailed) is .000 , it means there is significant difference in the usability of new system and old system and the new system is more usable as compared to the old one $\mathrm{t}(249)=16.369, \mathrm{p} \leqslant .05$ as suggested by Julie Pallant (2011).

Paired sample T-test was also performed between the efficiency construct of RFID (NFC) system and the old system. Table XX shows that total mean for RFID (NFC) system is 5.010 whereas a total mean for usability of the old system is 2.564. Table XXI shows the result of paired sample T-test. The mean difference is computed as 2.446 with standard deviation of 1.834 , whereas the $t$ statistics is 21.080 , degree of freedom df is 249 with p-value that is sig(2-tailed) is .000 , it means there is significant difference in the efficiency of new system and old system and the new system is more efficient as compared to the old one $\mathrm{t}(249)=21.080, \mathrm{p} \leqslant .05$.

Paired sample T-test between the efficiency construct of RFID (NFC) system and the old system was performed and Table XXII shows that total mean for RFID (NFC) system is 4.772 whereas total mean for affordability of old system is 2.942. Table XXIII shows the result of paired sample T-test. The difference between the mean of new system and old system was 1.8300 with standard deviation of 2.121, furthermore the t statistics is 13.637, degree of freedom df is 249 with p-value that is $\operatorname{sig}$ (2-tailed) is .000 , it means there is significant difference in the affordability of new system and old system and the new system is more affordable as compared to the old one $\mathrm{t}(249)=13.637, \mathrm{p} \leqslant .05$.

Paired sample T-test was performed between the security construct of RFID (NFC) system and the old system. Table XXIV shows that total mean for RFID (NFC) system is 4.968 whereas total mean for the security of the old system is 3.012. Table XXV shows the result of paired sample T-test. The difference between the mean of new system and old system was 1.956 with standard deviation of 1.771 , furthermore the t statistics is 17.462, degree of freedom $\mathrm{df}$ is 249 with p-value that is $\operatorname{sig}$ (2-tailed) is .000 , it means there is significant difference in the security of new system and old system and the new system is more secure as compared to the old one $\mathrm{t}(249)=17.462, \mathrm{p} \leqslant .05$

Paired sample T-test was performed between the customer satisfaction construct of RFID (NFC) system and the old system. Table XXVI shows that total mean for RFID (NFC) system is 4.942 whereas total mean for the security of the old system is 2.942. Table XXVII shows the result of paired sample T-test. The difference between the mean of new system and old system was 2.000 with standard deviation of 1.633, furthermore the t statistics is 19.354, degree of freedom df is 249 with p-value that is $\operatorname{sig}$ (2-tailed) is .000 , it means there is significant difference in the satisfaction level of new system and old system and the respondent are more satisfied with new system as compared to the old one $\mathrm{t}(249)=19.354, \mathrm{p} \leqslant .05$

TABLE XVIII. PAIRED SAMPLES STATISTICS (USABILITY)

\begin{tabular}{|l|l|r|r|r|r|}
\hline \multicolumn{2}{|c|}{} & \multicolumn{1}{c|}{ Mean } & N & \multicolumn{1}{c|}{ Std. Deviation } & \multicolumn{1}{c|}{ Std. Error Mean } \\
\hline \multirow{2}{*}{ Pair 1 } & Usability new system & 5.0373 & 250 & 1.47905 & .09354 \\
\cline { 2 - 6 } & Usability old system & 3.0147 & 250 & 1.25026 & .07907 \\
\hline
\end{tabular}

TABLE XIX. PAIRED SAMPLES TEST (USABILITY)

\begin{tabular}{|c|c|c|c|c|c|c|c|c|c|}
\hline & & \multicolumn{5}{|c|}{ Paired Differences } & & \multirow{3}{*}{ df } & \multirow{3}{*}{ Sig. (2-tailed) } \\
\hline & & \multirow[t]{2}{*}{ Mean } & \multirow{2}{*}{$\begin{array}{l}\text { Std. } \\
\text { Deviation }\end{array}$} & \multirow{2}{*}{$\begin{array}{l}\text { Std. Error } \\
\text { Mean }\end{array}$} & \multicolumn{2}{|c|}{$\begin{array}{l}\text { 95\% Confidence Interval of } \\
\text { the Difference }\end{array}$} & & & \\
\hline & & & & & Lower & Upper & & & \\
\hline Pair 1 & $\begin{array}{l}\text { Usability new system - } \\
\text { usability old system }\end{array}$ & 2.02267 & 1.95382 & .12357 & 1.77929 & 2.26604 & 16.369 & 249 & .000 \\
\hline
\end{tabular}

TABLE XX. PAiRED SAMPLES Statistics (EFFiCIENCY)

\begin{tabular}{|l|l|l|l|l|l|}
\hline \multicolumn{2}{|l|}{} & Mean & N & Std. Deviation & Std. Error Mean \\
\hline \multirow{2}{*}{ Pair 1 } & Efficiency new system & 5.0102 & 250 & 1.37775 & .08714 \\
\cline { 2 - 7 } & Efficiency old system & 2.5640 & 250 & 1.28611 & .08134 \\
\hline
\end{tabular}


TABLE XXI. PAIRED SAMPLES Test (EFFICIENCY)

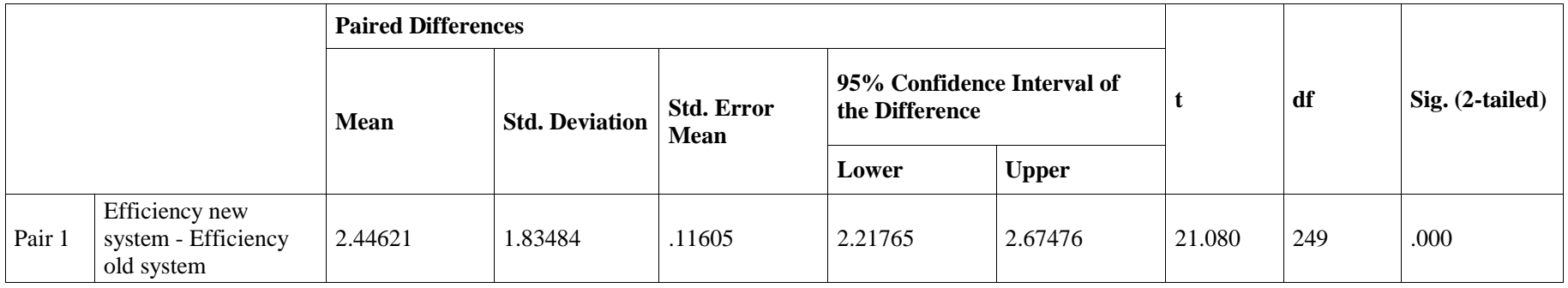

TABLE XXII. PAIRED SAMPLES STATISTICS (AFFORDABILITY)

\begin{tabular}{|l|l|l|l|l|l|}
\hline \multicolumn{2}{|c|}{} & Mean & N & Std. Deviation & Std. Error Mean \\
\hline \multirow{3}{*}{ Pair 1 } & Affordability new system & 4.7727 & 250 & 1.43530 & .09078 \\
\cline { 2 - 6 } & Affordability old system & 2.9427 & 250 & 1.46833 & .09287 \\
\hline
\end{tabular}

TABLE XXIII. PAIRED SAMPLES TEST (AFFORDABILITY)

\begin{tabular}{|c|c|c|c|c|c|c|c|c|c|}
\hline & & Paired D & ences & & & & & & \\
\hline & & Mean & Std. & Std. Error & $\begin{array}{l}95 \% \text { Co } \\
\text { the Diffe }\end{array}$ & Interval of & $\mathbf{t}$ & df & Sig. (2-tailed) \\
\hline & & & & & Lower & Upper & & & \\
\hline Pair 1 & $\begin{array}{l}\text { Affordability new system } \\
\text { - Affordability old system }\end{array}$ & 1.83007 & 2.12191 & .13420 & 1.56576 & 2.09439 & 13.637 & 249 & .000 \\
\hline
\end{tabular}

TABLE XXIV.PAIRED SAMPLES STATISTICS(SECURITY)

\begin{tabular}{|c|c|c|c|c|c|}
\hline & & Mean & $\mathbf{N}$ & Std. Deviation & Std. Error Mean \\
\hline \multirow{2}{*}{ Pair 1} & Security new system & 4.9689 & 250 & 1.27688 & .08076 \\
\hline & Security old system & 3.0127 & 250 & 1.29658 & .08200 \\
\hline
\end{tabular}

TABLE XXV. PAIRED SAMPLES TEST (SECURITY)

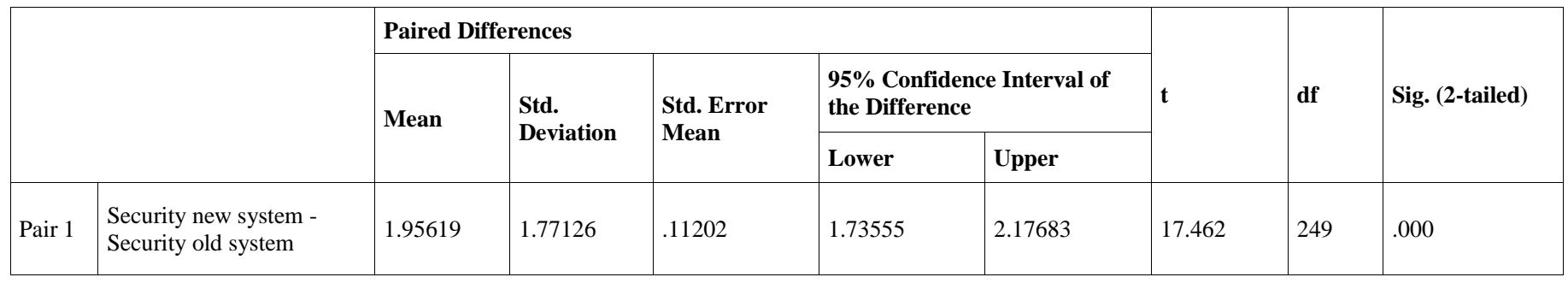

TABLE XXVI.PAIRED SAMPLES STATISTICS(SATISFACTION)

\begin{tabular}{|l|c|c|c|c|r|}
\hline \multicolumn{2}{|c|}{} & Mean & N & Std. Deviation & Std. Error Mean \\
\hline Pair 1 & Satisfaction new system & 4.9427 & 250 & 1.18880 & .07519 \\
& Satisfaction old system & 2.9427 & 250 & 1.10213 & .06970 \\
\hline
\end{tabular}

TABLE XXVII. PAIRED SAMPLES TEST (SATISFACTION)

\begin{tabular}{|c|c|c|c|c|c|c|c|c|c|}
\hline & & \multicolumn{5}{|c|}{ Paired Differences } & \multirow{3}{*}{$\mathbf{t}$} & \multirow{3}{*}{ df } & \multirow{3}{*}{ Sig. (2-tailed) } \\
\hline & & \multirow{2}{*}{ Mean } & \multirow{2}{*}{$\begin{array}{l}\text { Std. } \\
\text { Deviation }\end{array}$} & \multirow{2}{*}{$\begin{array}{l}\text { Std. Error } \\
\text { Mean }\end{array}$} & \multicolumn{2}{|c|}{$\begin{array}{l}\text { 95\% Confidence Interval of the } \\
\text { Difference }\end{array}$} & & & \\
\hline & & & & & Lower & Upper & & & \\
\hline Pair 1 & $\begin{array}{l}\text { Satisfaction new system - } \\
\text { Satisfaction old system }\end{array}$ & 2.00000 & 1.63395 & .10334 & 1.79647 & 2.20353 & 19.354 & 249 & .000 \\
\hline
\end{tabular}




\section{CONCLUSION}

In this paper, the evaluation of the proposed system has been performed. Results were demonstrated to compare the proposed system with the old systems which are described in the state of art section in the literature review. According to the results, the proposed system using RFID (NFC) technology for Halal food identification gained better satisfaction among all customers in any quality characteristics as compared to old Bar Code system. The usability, efficiency, security, affordability and customer satisfaction characteristics have been qualified for evaluation purpose. Moreover, the other characteristics of respondents have been evaluated to demonstrate the better results in using the RFID system for Halal food. This system will be beneficial from the commercial point of view as well as the customer point of view, as it is easy to use, efficient, and affordable. Secure and gain the customer satisfaction.

\section{REFERENCES}

[1] Bahrudin, Siti Sarah Mohd, Mohd Iskandar Illyas, and Mohamad Ishak Desa. 2011. "Tracking and tracing technology for halal product integrity over the supply chain." Electrical Engineering and Informatics (ICEEI), 2011 International Conference on. 1-7.

[2] Khairudin, N. E. Z. Bte. Halal Food Recognition System Using Barcode Nor Emilia Zetfy Bte Khairudin Report Submitted In Partial Fulfilment Of The Requirements For The Award Of the degree of Bachelor of Computer Sciences ( Software Engineering ) Faculty of Computer System \& Softwa. (2010).

[3] Brohi, I. A. et al. Near field communication enabled payment system adoption: A proposed framework. 2017 IEEE 3rd Int. Conf. Eng. Technol. Soc. Sci. 1-5 (2017). doi:10.1109/ICETSS.2017.8324199

[4] Bohn, Jurgen. 2006. "Prototypical implementation of location-aware services based on super-distributed RFID tags." In Architecture of Computing Systems-ARCS 2006, 69-83. Springer.

[5] Schwieren, Joachim, and Gottfried Vossen. 2009. "A design and development methodology for mobile RFID applications based on the ID-Services middleware architecture." Mobile Data Management: Systems, Services and Middleware, 2009. MDM'09. Tenth International Conference on. 260-266.

[6] Ahsan, Kamran, Hanifa Shah, and Paul Kingston. 2010. "RFID applications: An introductory and exploratory study." arXiv preprint arXiv: 1002.1179 .

[7] Tan, Mohd Iskandar Illyas, Raziah Noor Razali, Mohammad Ishak Desa, and others. 2012. "Factors influencing ICT adoption in halal transportations: A case study of Malaysian halal logistics service providers." International Journal of Computer Science Issues (International Journal of Computer Science Issues (IJCSI)) 9 (1): 62-71.

[8] Ali, N. I., Samsuri, S., Sadry, M., Brohi, I. A., \& Shah, A. (2017). Online shopping satisfaction in Malaysia: A framework for security, trust and cybercrime. Proceedings - 6th International Conference on Information and Communication Technology for the Muslim World, ICT4M 2016, 194-198. http://doi.org/10.1109/ICT4M.2016.43

[9] Fortes, N., \& Rita, P. (2016). Privacy concerns and online purchasing behaviour: Towards an integrated model. European Research on
Management and Business Economics, 22(3), 167-176. http://doi.org/10.1016/j.iedeen.2016.04.002

[10] Julie, P. (2011). Survival Manual. Training.Malik, M. E., Ghafoor, M. M., \& Iqbal, H. K. (2012). Impact of brand Image , service quality and price on customer satisfaction in Pakistan telecommunication sector. International Journal of Business and Social Science, 3(23), 123-130.

[11] Mohamed Syazwan Ab, T., \& Mohd Remie Mohd, J. (2012). Issues in Halal Packaging: A Conceptual Paper. International Business and Management, 5(2), 94-98. http://doi.org/10.3968/j.ibm.1923842820120502.1080

[12] Neilson, J. (2012). Usability 101: Introduction to Usability. Retrieved from https://www.nngroup.com/articles/usability-101-introduction-tousability/

[13] Ross, A., \& Willson, V. L. (2017). Basic and advanced statistical tests.

[14] Techopedia. (2017). Information Systems Security (INFOSEC). Retrieved from https://www.techopedia.com/definition/24840/information-systemssecurity-infosec

[15] Nasir, Mohd, Azah Norman, Shukor Fauzi, and Masliyana Azmi. 2011. "An RFID-based validation system for halal food." Int. Arab J. Inf. Technol. 8 (2): 204-211.

[16] Khosravi, M. et al. Halal Products Recognition Using Rfid/Nfc Technology. Sci. Int. 29, 687-692 (2017).

[17] Khosravi, M., Karbasi, M., Shah, A., Brohi, I. A. \& Ali, N. I. An adoption of halal food recognition system using mobile Radio Frequency Identification (RFID) and Near Field Communication (NFC). Proc. - 6th Int. Conf. Inf. Commun. Technol. Muslim World, ICT4M 2016 70-75 (2017). doi:10.1109/ICT4M.2016.74

[18] Neilson, J. Usability 101: Introduction to Usability. (2012). at https://www.nngroup.com/articles/usability-101-introduction-tousability/

[19] Webster, M. Definition of efficiency. (2018). at <https://www.merriamwebster.com/dictionary/efficiency>

[20] Ali, N. I., Samsuri, S., Sadry, M., Brohi, I. A. \& Shah, A. Online Shopping Satisfaction in Malaysia: A Framework for Security, Trust and Cybercrime. in 2016 6th International Conference on Information and Communication Technology for The Muslim World (ICT4M) 194-198 (IEEE, 2016). doi:10.1109/ICT4M.2016.048

[21] Techopedia. Information Systems Security (INFOSEC). (2017). at https://www.techopedia.com/definition/24840/information-systemssecurity-infosec

[22] Simon and Schuster, "Webster's New World Dictionary", Second College Edition, 1982.

[23] Malik, M. E., Ghafoor, M. M. \& Iqbal, H. K. Impact of brand Image , service quality and price on customer satisfaction in Pakistan telecommunication sector. Int. J. Bus. Soc. Sci. 3, 123-130 (2012).

[24] Nunnally, J. (1978), Psychometric theory, New York: McGraw-Hill.

[25] Cronbach, L. J. Coefficient alpha and the internal structure of tests. Psychometrika 16, 297-334 (1951).

[26] Tavakol, M. \& Dennick, R. Making sense of Cronbach's alpha. Int. J. Med. Educ. 2, 53-55 (2011).

[27] Julie, P. SPSS Survival Manual. Training (2011).

[28] Ross A., Willson V.L. (2017) Paired Samples T-Test. In: Basic and Advanced Statistical Tests. SensePublishers, RotterdamG. Eason, B. Noble, and I. N. Sneddon,"On certain integrals of Lipschitz-Hankel 